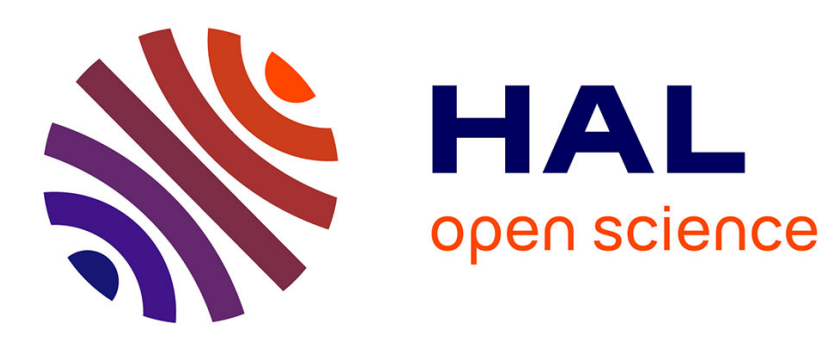

\title{
Electrochemical intercalation of alkali metals into superconducting oxide phases
}

\author{
W. Macklin, Sophie Claude, Valerie Brien, P. Moseley
}

\section{To cite this version:}

W. Macklin, Sophie Claude, Valerie Brien, P. Moseley. Electrochemical intercalation of alkali metals into superconducting oxide phases. Journal of Materials Chemistry, 1992, 2 (4), pp.439-441. 10.1039/jm9920200439 . hal-02882494

\section{HAL Id: hal-02882494 \\ https://hal.science/hal-02882494}

Submitted on 22 Oct 2020

HAL is a multi-disciplinary open access archive for the deposit and dissemination of scientific research documents, whether they are published or not. The documents may come from teaching and research institutions in France or abroad, or from public or private research centers.
L'archive ouverte pluridisciplinaire HAL, est destinée au dépôt et à la diffusion de documents scientifiques de niveau recherche, publiés ou non, émanant des établissements d'enseignement et de recherche français ou étrangers, des laboratoires publics ou privés. 
To quote this work :

W. Macklin, S. Claude, V. Brien, P. Moseley, Electrochemical Intercalation of Alkali-Metals

into Superconducting Oxide Phases, J. Mater. Chem. 2 (1992) 439-441. https://doi.org/10.1039/jm9920200439, hal-0288249

Thank you.

\title{
Electrochemical Intercalation of Alkali Metals into Superconducting Oxide Phases
}

\author{
W. J. Macklin, S. Claude, V. Brien and P. T. Moseley* \\ Applied Electrochemistry Department, AEA Industrial Technology, Harwell Laboratory, Oxfordshire OX11 \\ ORA, UK
}

The electrochemical intercalation of alkali metals into several superconducting oxide phases has been carried out by galvanostatic discharge of an electrochemical cell. In each case intercalation appears to result in a decrease in the volume fraction of the superconducting phase. Intercalation of lithium into an indium-doped $\mathrm{Bi}-\mathrm{Sr}-\mathrm{Ca}-\mathrm{Cu}$ oxide gave a material of approximate composition $\mathrm{Li}_{0.23} \mathrm{Bi}_{1.9} \mathrm{In}_{0.1} \mathrm{Sr}_{2} \mathrm{CaCu}_{2} \mathrm{O}_{8+\delta}$ which the superconducting onset temperature, $T_{c}$ was increased by ca. $15 \mathrm{~K}$ above that of the original compound. Intercalation into other superconducting bismuth oxides produced increases in some cases, and decreases in others. Intercalation into the thallium 2212 superconductor produced no discernible change in $T_{c}$.

Keywords: Electrochemical intercalation ; Intercalation ; Superconducting oxide

\section{Introduction}

Transition-metal oxides and sulfides capable of the reversible intercalation of small guest ions such as $\mathrm{Li}^{+}$are of interest as possible solid-state electrodes in high-energy density secondary batteries and electrochromic devices [1,2]. In this connection attention has focused on a number of layered compounds, including the metal oxides $\mathrm{V}_{2} \mathrm{O}_{5}$ [3], $\mathbf{M o O}_{3}$ [4] and $\mathrm{Cu}_{2} \mathrm{~V}_{2} \mathrm{O}_{7}$ [5]. The intercalation process involves a co-injection of lithium ions and electrons into the host structure. This usually results in a change in the interlayer separation in order to accommodate the guest $\mathrm{Li}^{+}$ions, together with a modification in the electron energy-band structure of the host material. Similar intercalation reactions are to be expected from the layered copper perovskite structures currently being studied for high temperature superconductivity. Indeed, recently, the intercalation of silver into the superconductor $\mathrm{Bi}_{2} \mathrm{Sr}_{2} \mathrm{CaCu}_{2} \mathrm{O}_{8+\delta}$ was reported to enhance the $T_{c}$, by ca. $15 \mathrm{~K} \mathrm{[6]}$ and the intercalation of lithium has been reported to produce a similar effect.

On the other hand, the chemical intercalation of lithium into $\mathrm{YBa}_{2} \mathrm{Cu}_{3} \mathrm{O}_{7-\delta}$ causes a degradation in superconducting properties [9], and the electrochemical intercalation of lithium fails to render $\mathrm{PrBa} 2 \mathrm{Cu} 30$, superconducting [10]. The intercalation of iodine from the vapour phase causes substantial increases in the $c$ axis of BiSCCO phases but only small decreases in $T_{c}[11]$.

In this paper we report the electrochemical intercalation of lithium and sodium into a number of high- $T_{C}$, superconducting

oxide phases, including indium- and lead-doped materials, and the effect on their superconducting behaviour. The substitution of alkali metals into the $\mathrm{Bi}-\mathrm{Sr}-\mathrm{Ca}-\mathrm{Cu}-\mathrm{O}$ system during conventional synthesis can lead to a significant decrease in the temperature of formation of the 2212 phase, and result in an increase in $T_{c}$, with the smaller alkali-metal ions such as lithium. An onset temperature of $98 \mathrm{~K}$ has been reported for a $\mathrm{Bi}-\mathrm{Sr}-\mathrm{Ca}-\mathrm{Cu}$ oxide 2212 phase in which lithium is partially substituted for copper [12]. Furthermore, the inclusion of lithium in superconducting Bi-Sr-Ca-Cu oxide flexible whiskers, prepared by heating a melt-quenched plate in oxygen, is effective in raising the $T_{c}$, in both the 2212 phase and the 2223 phase [13].

Electrochemical intercalation affords not only the advantage of room-temperature implementation, but also the ease of control of the level of doping in the superconductor. Given the present incomplete explanation of the mechanism of superconductivity in the high- $T_{c}$, ceramic materials the structural and electronic changes observed in the host as a consequence of the intercalation of alkali metals and their effect on the superconductivity may provide useful insight into understanding this phenomenon.

\section{Experimental}

$\mathrm{Bi}-\mathrm{Sr}-\mathrm{Ca}-\mathrm{Cu}$ oxide samples were prepared by solid-state reaction. Powders prepared by mixing the appropriate quantities of $\mathrm{Bi}_{2} \mathrm{O}_{3}, \mathrm{CuO}, \mathrm{SrCO}_{3}$, together with $\mathrm{In}_{2} \mathrm{O}_{3}$ or $\mathrm{PbO}$ for the doped samples, were pressed into pellets and 
sintered at $860^{\circ} \mathrm{C}$ for $72 \mathrm{~h}$. The $\mathrm{Bi}_{2} \mathrm{Sr}_{2} \mathrm{CaCu}_{2} \mathrm{O}_{8+\delta}$ and indium-doped phases were sintered in air, while the lead-doped $\mathrm{Bi}$ $\mathrm{Sr}-\mathrm{Ca}-\mathrm{Cu}$ oxide material was sintered in an argon-oxygen atmosphere. Thallium compounds were prepared by similar methods starting with mixtures including $\mathrm{Tl}_{2} \mathrm{O}_{3}$ rather than $\mathrm{Bi}_{2} \mathrm{O}_{3}$ and firing at $916{ }^{\circ} \mathrm{C}$ specimens wrapped in gold foil inside a sealed evacuated silica tube.

X-Ray diffraction patterns were obtained using a Siemens D500 diffractometer employing $\mathrm{Cu}-\mathrm{K}_{\alpha}$ radiation and incorporating pulse height discrimination and a curved graphite secondary monochromator. Data collection and processing over the range $4^{\circ}<2$ theta $<70^{\circ}$ were controlled by a PDP $11 / 23$ plus computer.

Magnetic inductance measurements were made by measuring the self-inductance of a transversely wound coil adjacent to the specimen using a Hewlett Packard 4274 A LCR meter. The sample probe was lowered down the temperature gradient set up above the surface of liquid helium. The temperature gradient was ca. $1 \mathrm{~K} \mathrm{~mm}^{-1}$ depending on the level of liquid in the dewar. For routine measurements, the magnetic flux density produced by the coil was $<10^{-4} \mathrm{~T}$.

The intercalation of lithium and sodium into superconducting phases has been carried out by galvanostatic discharge of electrochemical cells containing a superconductor working electrode, alkali-metal counter electrode and alkali-metal ion conducting electrolyte. In the two-terminal Teflon cell configuration, the working and counter electrodes were separated by pads of Whatman filter paper soaked in the electrolyte, a $1 \mathrm{~mol} \mathrm{dm}^{-3} \mathrm{MClO}_{4}(\mathrm{M}=\mathrm{Li}$ or Na) solution in propylene carbonate. Cells were assembled in a dry room $\left(\mathrm{T}=20^{\circ} \mathrm{C}\right.$, dew point temperature $\left.=-30^{\circ} \mathrm{C}\right)$.

The accuracy of the temperature measurements was checked by occasional calibration with a standard specimen of $\mathrm{YBa}_{2} \mathrm{Cu}_{3} \mathrm{O}_{7-\delta}(T c=93 \mathrm{~K})$. This process repeatably indicated that the temperature for sharp conductivity onsets was measured to an accuracy of $+/-1 \mathrm{~K}$.

The cells were discharged at room temperature, to a voltage of $1.0 \mathrm{~V}$, using a microprocessor-controlled multichannel galvanostat. The current densities were in the range $10-100 \mu \mathrm{A} \mathrm{cm}^{-2}$. The mole fraction of the intercalated alkali metal in the superconducting phase was calculated from the capacity obtained on the discharge together with the weight of the pellet. After discharge, cells were dismantled, and the electrolyte was removed from the pellet surface prior to the measurement of susceptibility.

\section{Results and Discussion}

Details of the oxides used as cathodes and the compositions after intercalation are given in Table 1. X-Ray diffraction indicated that the samples were essentially single phase, but after intercalation the diffraction lines were significantly broadened. The intercalation process did not bring about any change in the lattice parameters of the materials as great as the relevant standard deviation. Although the open-circuit voltages on assembly of the lithium cells were in the range $2.9-3.4 \mathrm{~V}$, there was no significant capacity at these high voltages and the discharge voltage rapidly fell below $2 \mathrm{~V}$ in each case. Voltages in the sodium cells were typically $0.3 \mathrm{~V}$ lower than those in the analogous lithium cells. Discharge curves for electrochemical cells containing three of the superconducting BiSCCO pellets and lithium anodes are given by way of example in Fig. 1.

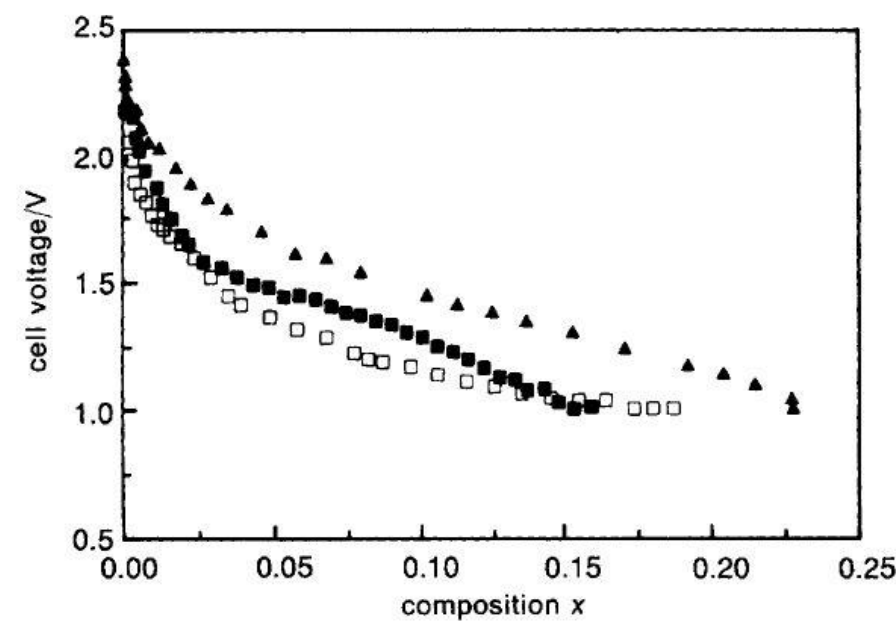

Fig. 1 Discharge curves for three of the electrochemical cells incorporating lithium anodes and $\mathrm{BiSCCO}$ family cathodes: $\quad \square, \mathrm{Bi}_{2} \mathrm{Sr}_{2} \mathrm{CaCu}_{2} \mathrm{O}_{8+\delta} ; \quad \Delta, \mathrm{Bi}_{1.9} \mathrm{In}_{0.1} \mathrm{Sr}_{2} \mathrm{CaCu}_{2} \mathrm{O}_{8+\delta}$; ש, $\mathrm{Bi}_{1.84} \mathrm{~Pb}_{0.34} \mathrm{Sr}_{2} \mathrm{Ca}_{2} \mathrm{Cu}_{3} \mathrm{O}_{10}$

The discharge voltages were comparable to that observed in the lithium-copper oxide primary cell [14], which exhibits a plateau at ca. $1.5 \mathrm{~V}$. The discharge curves for the indium- and the lead-doped samples decreased monotonically with alkalimetal insertion, indicative of a single-phase reaction, whereas the discharge curve for the $\mathrm{Bi}_{2} \mathrm{Sr}_{2} \mathrm{CaCu}_{2} \mathrm{O}_{8+\delta}$ material had a short step at ca. $1.4 \mathrm{~V}$ which may be associated with a two phase region in the intercalation process. 
Inductance versus temperature plots, before and after intercalation of the two doped phases are given in Fig. 2. In each case there appeared to be a decrease in the volume fraction of the superconducting phase as a result of intercalating lithium. The lithiated samples no longer demonstrated the sharp downturn in inductance at the critical temperature, but rather had a smoother decrease in inductance with decreasing temperature. The onset of the decrease in inductance appeared to have moved to higher temperature after lithium intercalation. In the case of $\mathrm{Bi}_{1.9} \mathrm{In}_{0.1} \mathrm{Sr}_{2} \mathrm{CaCu}_{2} \mathrm{O}_{8+\mathrm{d}}$ the intercalation of lithium resulted in a significant increase in the onset temperature of $c a .15 \mathrm{~K}$ and the data [Fig. 2(a)] closely resembled the data reported for intercalation of lithium into $\mathrm{Bi}_{2} \mathrm{Sr}_{2} \mathrm{CaCu}_{2} \mathrm{O}_{8+\delta}$.
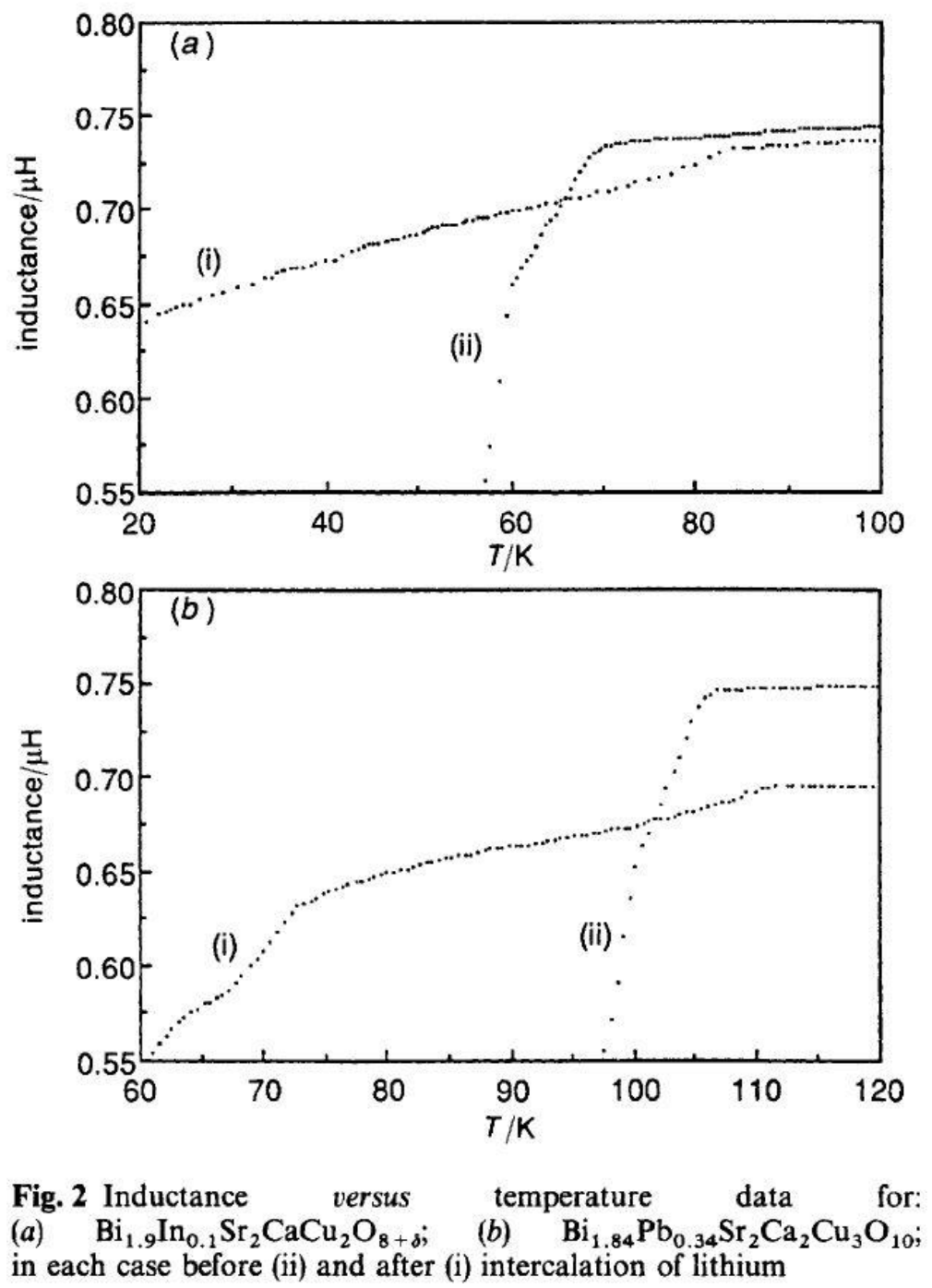

Overall, the lithium intercalation in these experiments appeared to produce two contrasting effects: a decrease in the fraction of the material that was superconducting, but an increase in the $T$, onset of that fraction. These observations may be rationalised by assuming that the method used to introduce lithium to the starting material was not producing a homogeneous modification, for example grain surfaces might accept more lithium than the bulk.

However, intercalation experiments with other materials produced (Table 1) somewhat different results. The decrease in the volume fraction of superconducting material was a general feature, but the effect on the superconducting transition temperature, $T_{c}$ was only positive in cases where the initial oxide had a $T_{c}$, significantly lower than the optimum value known to be achievable by thermal redox adjustment. In cases where the oxide had initially exhibited a $T_{c}$, near the known maximum value, the effect of intercalation was to cause a decrease in the transition temperature.

Intercalation of both lithium and sodium into the thallium 2212 superconducting oxide left the superconducting transition unchanged for smaller amounts of alkali-metal incorporated but the volume fraction of superconducting material decreased significantly. 


\section{Conclusions}

It is clear that stoichiometric changes that affect the oxidation state of the original metal ions play an important role in determining the superconducting properties of complex copper oxides. In the past such changes have been effected largely by appropriate choice of oxygen partial pressure during thermal treatment [15].

The intercalation of alkali metals at room temperature represents an alternative method by which the oxidation state of the metals originally present in the superconductor may be modified, probably without altering the oxygen inventory. The experiments described have indicated that the employment of relatively minor alkali-metal loadings can have rather large effects.

The optimum transition temperature achievable by using electrochemical intercalation to control the redox chemistry of the superconductor appears to be similar to that achievable by conventional thermal means.

The authors are grateful to Dr. J Perks and Miss J. Hemsworth for help with the inductance measurements, M. Fones for X-ray diffraction, and Mr. R. C. Piller for providing specimens of BiSCCO. This work was partially funded by the Admiralty Materials Laboratory, B.D.H. Ltd., BICC, ENEL and Ford of Europe Inc.

\section{References}

1. M. S. Whittingham, Prog. Solid State Chem., 1978, 12, 41.

2. M. Green, Thin Solid Films, 1976, 38, 89.

3. N. Kumagai, K. Tanno, T. Nakajima and N. Watanabe, Electrochim. Acta, 1983, $28,17$.

4. P. A. Christian, J. N. Carides, F. J. Di Salvo and J. V. Waszczak, J. Electrochem. SOC., 1980, 127, 2315.

5. J. Yamaki and A. Yamaji, Physica B, 1981, 105, 466.

6. G. A. Scholz and F. W. Boswell, Solid State Commun., 1990, 74, 959.

7. W. J. Macklin, UK Pat., 91-22495.6, 1991

8. P. Strobel, B. Bonnet, C. Mouget and B. Souletie, Physica C, 1990, 172, 193.

9. M. A. Alario-Franco, E. Moran, A. Varez, J. Santamaria and F. Sanchez-Queseda, Solid State Ionics, 1990,44, 73.

10. J-H. Choy, S-H. Chun and S-G. Kang, Bull. Korean Chem. Soc., 1990, 11, 561.

11. X. D. Xiang, A. Zettl, W. A. Vareka, J. L. Corkill, T. W. Barbee III and M. L. Cohen, Phys. Rev. B 1991, 43, 11496.

12. T. Kawai, T. Horiuchi, K. Mitsui, K. Ogura, S. Takagi and S. Kawai, Physica C, 1989, 161, 561.

13. I. Matsubara, H. Tanigawa, T. Ogura, H. Yamashita, M. Kinoshita and T. Kawai, Appl. Phys. Lett, 1990, 56, 2141.

14. Modern Batteries, ed. C. A. Vincent, Edward Arnold, London, 1984, p.153.

15. A. Mackenzie, E. Marseglia, I. Marsden, G. Lonzarich, C. Chen and B. Wanklyn, Physica C, 1989, 162-164, 1029. 